\title{
MODELING OF SELECTED LOAD-BEARING STRUCTURES USING THE TRUSS AND BEAM ELEMENTS
}

\author{
Anna Jaskot, Szczepan Śpiewak \\ Institute of Mechanics and Fundamentals of Machinery Design \\ Czestochowa University of Technology, Czestochowa, Poland \\ jaskot@imipkm.pcz.pl,spiewak@imipkm.pcz.pl
}

\begin{abstract}
The article presents the methodology of adjusting the usable properties of rodlike and beam elements for modeling the complex load-bearing structures. The basic object of consideration was the single-row slewing ball bearing. In this paper the mapping issues of usable qualities of the slewing bearings are summarized in relation to use of the finite element method. The emphasis is primarily on using the rod-like and beam elements for modeling the contact phenomena in the ball-raceway contact zone. In addition, ideas for use of the beam elements to modeling bearing bolts were presented.
\end{abstract}

Keywords: finite elements type of truss and beam, contact zone ball bearings-raceway, slewing bearings, computational mechanics

\section{Introduction}

The widespread use of numerical methods for strength calculations of loadbearing structures, and in particular the finite element method, causes an increase in the computing power demand of computers.

This is the case of the technical objects in particular, which are made up of many individual components with complex shapes. Such systems require suitably dense discretization using the finite elements. The consequence is the significant task expansion. The dimension of the stiffness matrix increases in the issues of the continuum mechanics including the elasticity and plasticity theory. The increasing time of performing the calculation is a disadvantageous effect. In order to improve the effectiveness of all kinds of design works in mechanical engineering is increasingly being introduced to all kinds of replacement elements, the purpose of which is the representation of individual physical objects in the global model.

In the practical modelling, the finite elements are used for which the elementary stiffness matrices are in minimum sizes, and the material models can be described with the simplest functions with the least number of function parameters. The finite element examples of these features are the rod-like and beam elements $[1,2]$. Commonly, in engineering calculations, the elements represent the objects such as: 
the spans of structures, coil springs, flat springs, mounting parts, support structures and linkage structure. Selection of the type of the element is not easy because it is determined by the nature of the modeling phenomena and the level of simplification. This work focused on the practical use of the rod-like elements to the modeling of the contact zone of the single-row slewing ball bearing, as well as on using beam elements to modeling the bearing bolt. This nomenclature applies to the finite element generated in accordance with the procedures of ADINA system [3].

\section{The conditions of the rod and beam element}

The rod member [2] "truss" type [3] in its simplest form is described by two nodes $[i, j]$, which in the spatial load condition will be subjected to the translation only. The generalized coordinate vector $U$-nodes of the rod-like element is described as follows:

$$
U=\left[\begin{array}{llllll}
u_{x i} & u_{y i} & u_{z i} & u_{x j} & u_{y j} & u_{z j}
\end{array}\right]^{T}
$$

where the indexes $x, y, z$ represent the directions in the global coordinate system.

All the components of the nodal displacement vector and loads can be projected to the direction of the rod-like element, which is not subjected under the load. There is also a possibility to determine the balance of the internal and external forces conditions in the scope of the linear deformation according to the equation (boil down to the one-dimensional state of stress):

$$
F=E A \frac{\partial u}{\partial x}
$$

where:

$F$ - value of the resultant of the external load $[\mathrm{N}]$,

$E$ - the proportionality coefficient (modulus of elasticity) [MPa],

$A$ - cross-sectional area of the rod-like element $\left[\mathrm{m}^{2}\right]$.

The result is the $2 \times 2$ stiffness matrix, to which you will enter the initial length of $\operatorname{rod} l_{0}$, the cross-sectional area $A$, the proportionality coefficient $E$, which characterizes the elastic property of the material. A characteristic feature of the "truss" type finite element is unchangeable to the deformation of the value of the crosssectional area. An additional attribute in the practical use of this type of elements is the ability to define a multilinear characteristic stress-strain of the isotropic material $(\sigma-\varepsilon)[3]$. As a result can be determined the value of the normal stress.

The beam type [3] element [2] in its simplest form is defined as the finite two nodal element (nodes $i, j$ ). In contrast to the rod-like element, the nodal values which are forming a generalized coordinates vector were extended by the components of the rotation $\alpha$. 


$$
U=\left[\begin{array}{llllllllllll}
u_{x i} & u_{y i} & u_{z i} & \alpha_{x i} & \alpha_{y i} & \alpha_{z i} & u_{x j} & u_{y j} & u_{z j} & \alpha_{x j} & \alpha_{y j} & \alpha_{z j}
\end{array}\right]^{T}
$$

Effects of the external loads of the beam element are directly dependent on the direction of action all forces defined in the nodes and referred to the main central axis of inertia of the cross-section. Hence the vector of the generalized external loads, the effects of which can be analyzed with the use of the beam elements, will have the form:

$$
F=\left[\begin{array}{llllllllllll}
F_{x i} & M_{y i} & M_{z i} & M_{x i} & M_{y i} & M_{z i} & F_{x j} & M_{y j} & M_{z j} & M_{x j} & M_{y j} & M_{z j}
\end{array}\right]^{T}
$$

where the individual values represent:

$F_{x}$ - the axial load (focused along the neutral axis), whose the impact for the longitudinal displacements value will depend on longitudinal stiffness $E A$,

$M_{x}$ - the torque, whose impact on the beam angle value will depend on the torsional stiffness $G J_{0}\left(J_{0}\right.$ - the polar moment of inertia of the cross-section of the beam), $M_{y}, M_{z}$ - the bending moments, the impact of which on the transverse displacements values and the deflection angles of the beams will depend on the flexural stiffness respectively $E J_{y} E J_{z}\left(J_{z}, J_{y}\right.$ - moments of inertia of the beam cross-section in relation to the $z$ and $y$ axis).

The result is a $12 \times 12$ stiffness matrix, into which is entered the initial length of the beam $l_{0}$, the cross-section $A$ of the modulus of elasticity $E$ and the shear modulus $G$, and the geometric moments of inertia of cross-section $J_{0}, J_{z}, J_{y}$. The material model for the finite "beam" type element is the isotropic elastic model.

The ADINA system for both truss and beam (isobeam) types can generate the elements with a greater number of nodes, but it should be noted that the shape functions are appropriately higher degrees which can be used for the modeling of objects with the known nonlinearity [1-3].

\section{The rod-like element and representation of the contact phenomena}

The special case concerning the modeling of the contact phenomena mechanics contact is interaction between two bodies for which contact surfaces are described by the various curves. According to the Hertz theory, the relationship between contact force of the two balls (about the linear elastic properties), and the rapprochement of the centres of curvature is nonlinear. This issue in a particular way concerns the ball bearings, in which cooperation between the rolling parts and the raceways has a contact point for the ball bearings and the contact line for the rolling bearings. From the point of view of the endurance modeling of the anti-friction bearing, the specific objects are the slewing bearing (Fig. 1).

The characteristic features of the slewing bearings are large values of the rolling diameters $d_{t}$ (up to a few meters), a different mounting system of the bearing rings to the bodies and the heads (usually using the mounting bolts located on the circuits of the rings with the holes), the static nature of the work (most often work as slowly rotating with rotational velocity not exceeding several revolutions per 
minute), the specificity of the load (large values of the load axial forces $Q$, and the radial forces $H$, and the tilting moments $M$ ), a large number of rolling parts (coming up to several hundred), notched on the circuit of one of the rings the toothed rim, the high flexural-torsion susceptibility of the bearing rings in relation to the seating susceptibility and the zone contact susceptibility the roller element - the raceway, the use of other materials for the production of the rings and roller parts. A key factor in the choice of the slewing bearing is the static carrying capacity including the information about the values of the external boundary loads $M, Q$ and $H$, which the given bearing is able to transfer. The components of these forces are transmitted through the support structures, the bolts and the rings for the different rolling parts.

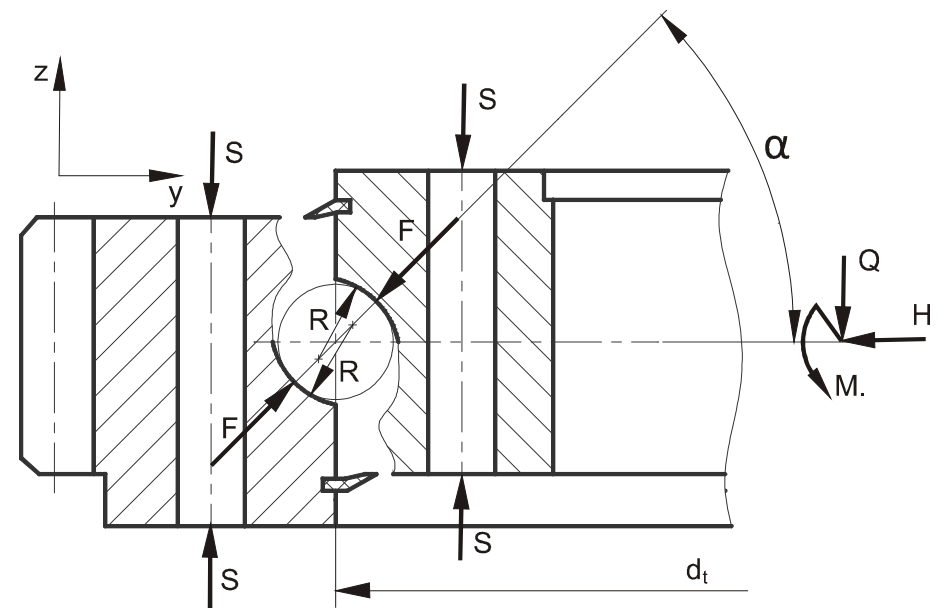

Fig. 1. One-row ball slewing bearing

In respect to this, the static carrying capacity of the bearing will be dependent on the nascency permissible value of reaction between the most effort of rolling elements and bearing's raceway. Therefore, the primary objective in the modeling of the slewing bearings is to determine the distribution of the forces $F$ acting on the respective contact zones. The value of the allowable load of the balls and rollers can be calculated on the basis of the formulas widely discussed in work [4]. Figure 1 presents the outline of the shape of the slewing bearing raceway in a single-row way with the four point ball-raceway contact zone. The raceway in $Y Z$ plane is defined by the radius $R$, while in a perpendicular plane with the direction of the force $F$ - the radius of curvature follows from the rolling diameter $d_{t}$ and the nominal angle $\alpha$ of the bearing action. Basic figures directly related to the contact zone of the slewing bearings are axial clearance, radial clearance and the angle of the rolling part. The axial clearance is defined as the highest relative displacement of one of the bearing rings on the direction of the longitudinal axis of symmetry of the bearing (when the second is fixed), without exerting emphasis. The radial clearance 
is defined by analogy to the axial clearance with only the difference that the displacements are defined in the radial direction. The impact of the bearing clearance to the load-bearing capacity has been analyzed among others in the work [5]. The bearing clearance, the displacements of the bearing rings, and the deformation of the contact zone cause a change in the angle of the rolling part. The angle of the ball bearings action is referred to as the angle between a straight line joining the ball contact point with the raceways, and a plane perpendicular to the longitudinal axis of symmetry of the bearing ( $x y$ plane bearing - Fig. 1). Taking account of these parameters in the slewing bearing model is of great importance since it allows one to set a range of exterior loads which allow one to avoid the adverse raceway edging occurrence. The edging of the raceway may cause local damage in the form of chipping, which is shown in Figure 2.

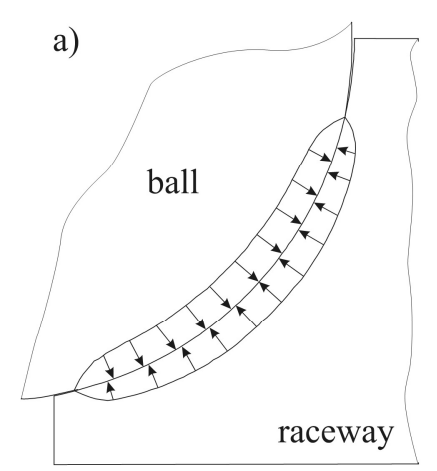

b)

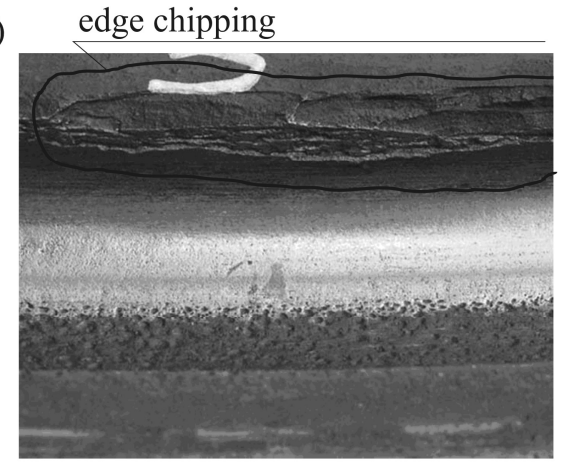

Fig. 2. The loading region of the contact zone (a), the damage of the bearing raceway (b)

Taking into account the large sizes of the rings, which are subjected to bending and torsion strains caused by the tension force $S$ (Fig. 1), the typical for bearings the deformities in the contact zones of the rolling parts and the bearing raceways, for the modeling of the slewing bearings usually applies the finite element method.

In order to minimize the size of the task, the roller elements in the global model of the bearing are replaced by the finite elements truss type. In the case of the rollers, there is a single roller [6] or multiplied [7] the number of rod-like elements. A good practice in the modeling of the balls is the use of the so-called superelements [8] i.e. the system, which in its original form consisted of two beam elements and one rod-like element attached by hinge. A slightly different system of the substitution elements, which represent the balls used in work [9], where to the connections with the superelements with the discretized raceways were used the coating components. The use of the replacement elements replaces the necessity of the multiple modeling of the contact task. Figure 3 represents the system of the superelement and the simulation principle of the phenomena occurring in the ballraceway contact zone of the slewing bearing, which is used by the authors of the article. 
a)

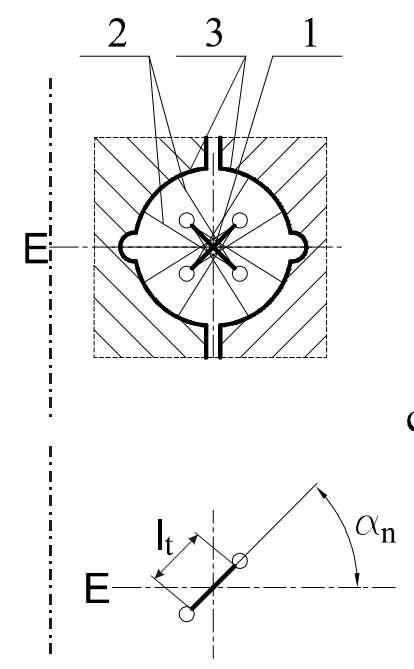

b)

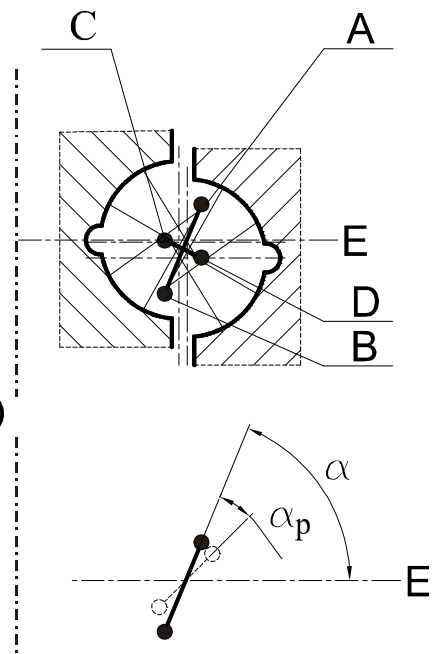

Fig. 3. Schematic position of bearing rings and substitute elements in a state before (a) and after (b) load inflicted with mapping changing of contact angle of balls in twin slewing bearing (c)

It is a set of two pairs of beam elements with a high stiffness 2 (with the invariable configuration of the position during the simulation loads) hingedly connected in a position of the centres of curvatures (points $A, B, C, D$ ) the bearing raceway 3 with a single rod-like element 1 . The rod-like element has a strictly defined length $l_{t}$ and the value of the cross-section area. The rod-like element has defined the material characteristics $\sigma-\varepsilon$. Through these characteristics the deformations occurring in the area of the contact zone of the contact pair are simulated. The length of the rod-like element should be calculated in accordance with the specimen [8].

$$
l_{s}=2 R-d_{k}
$$

where: $R$ - the radius of the raceway, $d_{k}$ - the diameter of the ball.

The cross-sectional area $A_{s}$ can be taken as an equal to the ellipse created as a contour of the deformed area contact for the limit load $F_{d o p}$, which on the basis of [5] can (approximately) be described by the formula [4]:

$$
\begin{aligned}
& A_{S}=\pi a_{H} b_{H}^{3} \sqrt{\frac{9\left(F_{d o p}\right)^{2}}{E^{2}\left(\frac{4-\frac{d_{k}}{d_{k}}}{d_{k}}+\frac{2 \cos \alpha}{d_{t}-d_{k} \cos \alpha}\right)^{2}}} \\
& F_{\text {dop }}=\frac{9,9626 \cdot 10^{7} d_{k}^{2}\left(\frac{H V}{750}\right)^{2}}{\left(\frac{858}{a_{H} b_{H}} \sqrt[3]{\left.d_{k}\left(\frac{4-\frac{d_{k}}{d_{k}}}{d_{k}}+\frac{2 \cos \alpha}{d_{t}-d_{k} \cos \alpha}\right)\right)^{2}}\right.}
\end{aligned}
$$


where remain symbols:

$a_{H}, b_{H}$ - the coefficients of the elliptic cross-section of the contact zone [5],

$H V$ - the surface hardness of Vickers of the raceway,

E $\quad$ - Young modulus.

The material characteristics of the truss type element $\sigma-\varepsilon$ shall be determined indirectly by using the contact zone characteristics $[6,10]$. The contact zone characteristics is a relation between the compression force of the rolling element to the raceway, and displacement of the geometric centre of the rolling element along the direction of the force. One of the ways to build these relations is to build the MES model of the contact zone, which as an example of the mesh is shown in Figure 4, where the four groups of the finite elements were separated representing different material models: the toughened zones of ball 2 and raceway 3 and the not hardened zones of ball 1 and raceway 4 . The $F$ force is oriented according to the direction of the nominal angle of bearing action. Such a model is loaded in steps by the increasing force $F_{i}(i$ - next step of the load) and furthermore to obtain the calculations of the displacements of a central node $\eta_{l i}$ and of the geometric structure of a ball.

That displacements in the presented model are consistent with the other nodes including in the upper plane, its symmetrical division of a ball.

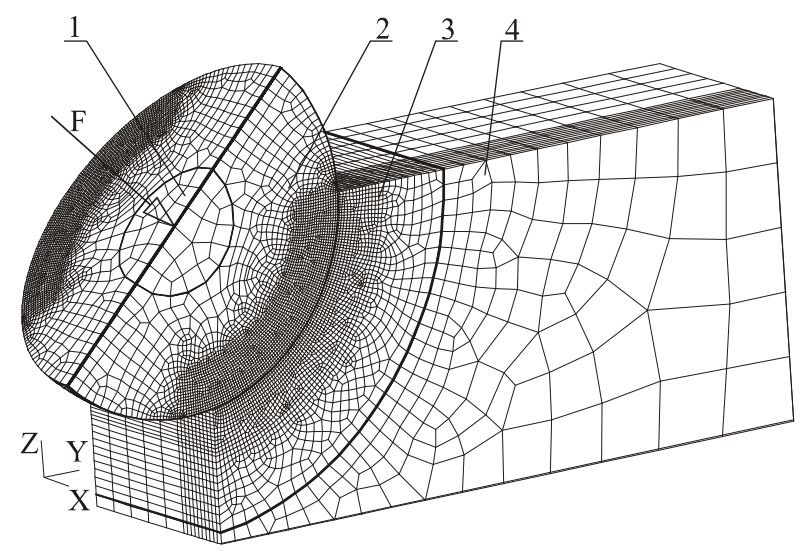

Fig. 4. The FE model of a mesh of the ball-raceway contact zone

A detailed description of the contents is presented in work [11]. In the global model of the bearing in which all of the carrying elements are subjected to the digitizing, and in particular bearing rings - the beam elements of the superelements are connected in the nodes in accordance with graduated angular positioning balls. Such a nodal connection causes the local increase in vulnerability which depends on the geometrical structure and size of a mesh of the finite element model. In order to avoid this the compensation of contact zone characteristics is performed in order to extract from the global model of the bearing the segment bearing ring with superelements (Fig. 5a), imposing the appropriate boundary conditions as shown in Figure $6 \mathrm{~b}$ and the obtaining displacements $\eta_{2 i}$ and the common node of the rod-like 
and beam elements of the superelement as a function of the force $F_{i}$ (in accordance with the load model - Fig. 4).

For each value of $F_{i}$ the force from the $\eta_{1 i}$ value is subtracted from the $\eta_{2 i}$ value and as result there is obtained the so-called characteristics of a superelement [6], which is shown in Figure 6a.

a)

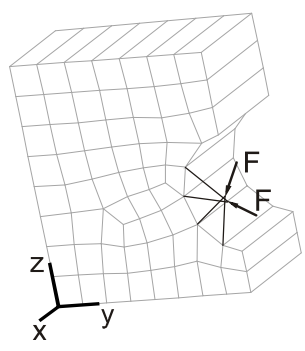

b)

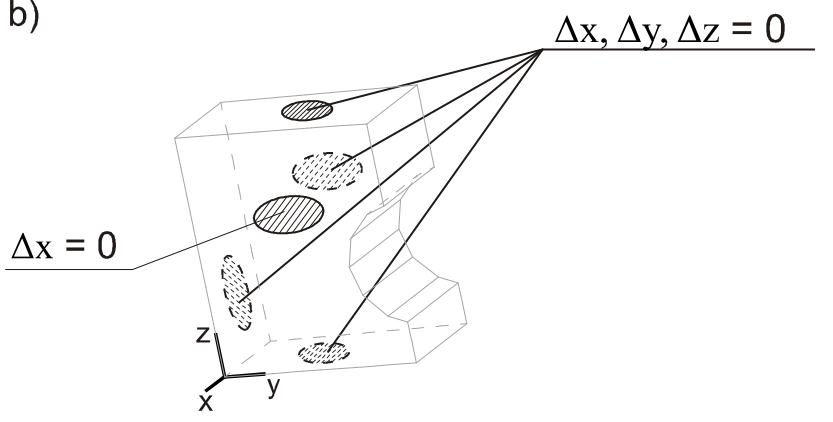

Fig. 5. The mesh of a model of ring segment with the superelement

a)

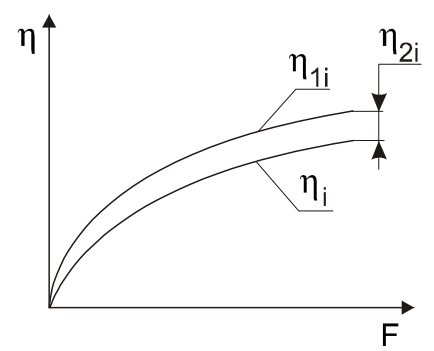

b)

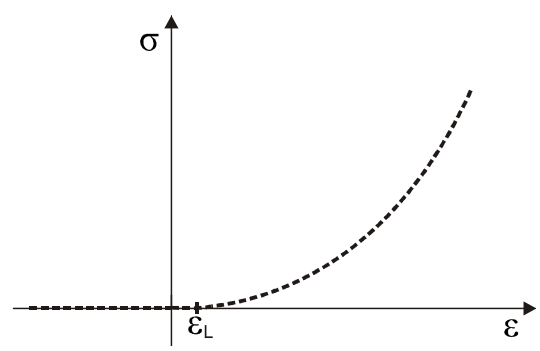

Fig. 6. The view method of the determining the replacement characteristics of the ball bearing (a), which was transformed into characteristic multilinear of the material model (b)

The transformations of the substitute characteristic of the superelement to the multilinear material characteristic $\sigma-\varepsilon$ of the rod-like element can be carried out on the basis of designs:

$$
\sigma_{i}=\frac{F_{i}}{A_{s}} \quad \varepsilon_{i}=\frac{\eta_{1 i}-\eta_{2 i}}{l_{s}}
$$

The material model of the rod-like element can be used to define the bearing clearance. The value of the assumed bearing clearance relative to the length of the rod-like element allows to calculate the deformation $\varepsilon_{\mathrm{L}}$, to which can assume a zero value of the $\sigma_{\mathrm{L}}$ stress. The example of the modified material characteristic defining the particular value of the clearance value is shown in Figure 6b. The values from the range of zero to $\varepsilon_{\mathrm{L}}$ represent the values of the mentioned clearance, and the 
other above $\varepsilon_{\mathrm{L}}$ represent the proper material characteristic of the elastic element. The impact analysis of the bearing clearance on the slewing bearing capacity performed with the using of the truss type elements is shown in work [12]. As shown in Figure 3, the displacements of the bearing rings caused by an external load make that the rod-like elements of the superelement may be subjected to tensile or compression. Because of the system of the superelement projected the compression load of the balls through the tensile strength of rod-like elements, their material characteristics for the negative deformations gives a zero stress value (Fig. 6b). On the basis of knowledge of coordinate systems nodes at points $A, B, C, D$ can be used to identify the angles of balls action [12].

\section{The beam element as a bearing screw}

With respect to the ad hoc strength of screw connections the best system is this load system which is from the axial tensile. In the slewing bearings the forces, which causes tensile the screws, are largely dependent on the tip-up moments and the participation of the axial forces in external load. In addition it turns out to be significant the transfer of loads from one ring to the other. A fragment of the global mess model of the single-row slewing ball bearing is presented in Figure 7.

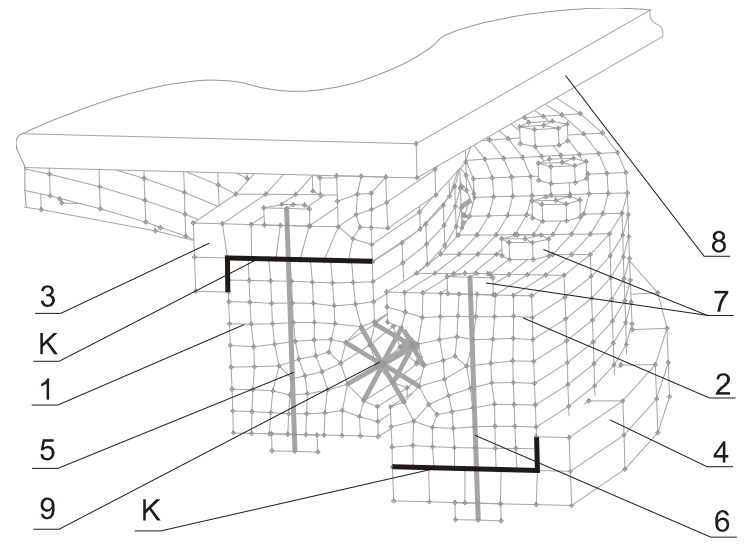

Fig. 7. The FE mesh segment of model of single-row ball slewing bearing

The external load given by the rigid plate 8 connected with the top cover 3 and the contact surface $K$ is transmitted to the inner ring of the bearing 1, then through the superelements on outer ring 2 and the lower cover 4 . In this connection the two nodal finite beam elements of the bolt type [3] play an important role, representing the internal bolts 5 and the external bolts 6 (Fig. 7). The nodes of the beams are connected to the central nodes of group 7, which were modeling the bolt heads and nuts. On the basis of the results presented in work [13] this type of simplification is used. Such modeling allows one to obtain the values of the reduced tension, which 
in a sufficient degree approximates the results to those, which can be obtained in a more cumbersome way. Thus this solution allows one to avoid the discretization of the solid screws by the 3D-Solid type elements and isolation of the free between-nodal space in finite element groups 1, 2, 3, 4 treated geometrically as the holes to bolt placement. For the bolt type elements the shape and the cross-section for the diameter of the bolt core have been defined, the material model and the initial tension forces of $S_{w}$. Such proceedings are justified, because the ADINA system in the initial iterations is looking for displacements of the model nodes caused by the forces applied to the bolt type elements [3]. Results of the practical use of the presented modeling method of the bearing bolts can be found in [14].

\section{Conclusions}

The examples of the practical use of the finite element properties are a result of literature review and the experience gained of the modeling of the phenomena occurring in the bearings. Developed models are versatile and allow one to quickly estimate the capacity of the loads of the bearing structures. In addition, the solutions allow one to develop the models that optimize design parameters. In addition, the solutions allow one to develop the models that optimize design parameters. The author of this work in the publication [15] has presented an original method for strength calculations of the gabions grid, which was also based on the truss type finite elements.

\section{References}

[1] Bathe K.J., Finite Element Procedures, Prentice-Hall, Inc. Simon \& Schuster / A Viacom Company, Upper Saddle River, New Jersey 1996.

[2] Rusiński E., Czmochowski J., Smolnicki T., Zaawansowana metoda elementów skończonych w ustrojach nośnych maszyn, Oficyna Wydawnicza Politechniki Wrocławskiej, Wrocław 2000.

[3] ADINA: Theory and Modeling Guide. Volume 1, ADINA R\&D, Inc., Watertown 2007.

[4] Brändlein J., Eschmann P., Hasbargen L., Weigand K., Die Wälzlagerpraxis, Vereinigte Fachverlag GmbH, Mainz 1998.

[5] Krzemiński-Freda H., Łożyska toczne, PWN, Warszawa 1989.

[6] Kania L., Analiza obciążenia wewnętrznego łożysk tocznych wieńcowych w aspekcie ich nośności statycznej, Seria Monografie, nr 111, Wydawnictwa Politechniki Częstochowskiej, Częstochowa 2005.

[7] Krynke M., Kania L., Mazanek E., Modelling the contact between the rolling elements and the raceways, Key Engineering Materials 2012, 490, 166-178.

[8] Smolnicki T., Fizykalne aspekty koherencji wielkogabarytowych łożysk tocznych i odkształcalnych konstrukcji wsporczych, Oficyna Wydawnicza Politechniki Wrocławskiej, Wrocław 2002.

[9] Daidie A., Chaib Z., Ghosn A., 3D simplified finite elements analysis of load and contact angle in a slewing ball bearing, Journal of Mechanical Design 2008, 130 (8), 082601.

[10] Kania L., Śpiewak S., Wyznaczanie charakterystyk zastępczych kulek w numerycznym modelowaniu łożysk tocznych wieńcowych, PAK 2009, 06, 334-337. 
[11] Kania L., Śpiewak S., Wpływ wybranych parametrów konstrukcyjnych na nośność statyczną łożysk tocznych wieńcowych podwójnych, Pomiary Automatyka Kontrola 2010, 56, 8, 930-933.

[12] Kania L., Śpiewak S., Wpływ luzu łożyskowego na nośność statyczną łożysk wieńcowych podwójnych, Transport Przemysłowy 2010, 2(8), 64-67.

[13] Mazanek E., Krynke M., Możliwości modelowania śrub mocujących łożysko wieńcowe, Transport Przemysłowy i Maszyny Robocze 2010, 2(8), 53-57.

[14] Kania L., Śpiewak S., Specyfika zmian oporu toczenia łożyska wieńcowego podwójnego w aspekcie doboru sił napięcia wstępnego śrub łożyskowych, Górnictwo Odkrywkowe 2014, $83,55,95-100$.

[15] Śpiewak S., Modelowanie i analiza wytrzymałościowa siatek gabionowych, Górnictwo Odkrywkowe 2014, 5-6, 55, 177-182. 